\title{
Previous grazing or clipping affects seed of Indian ricegrass
}

\author{
APOLLO B. ORODHO, R.L. CUANY, AND M.J. TRLICA
}

A.B. Orodho, dir., Western Agr. Res. Center, P.O. Box 169, Kakamega, Kenya; R.L. Cuany, Soil and Crop Sci. Dept., Colo. State Univ., Fort Collins, Colo 80523; M.J. Trlica, Rangeland Ecosystem Sci. Dept., Colo. State Univ., Ft. Collins, Colo 80523. Financial assistance was provided by the Food and Agriculture Organization of the United Nations through Project KEN/80/003, the U.S. Dept. of Agr. Competitive Grants Program on Desertification, and the Colo. State Univ. Agricultural Experiment Station. M.J. Trlica is the corresponding author.

Abstract

Previous heavy grazing for more than 50 years, compared with protection from livestock grazing, in the semi-arid area of Chaco Canyon in the southwestern United States did not result in any significant decrease in seed production potential of Indian ricegrass [Oryzopsis hymenoides (Roem. and Schult.) Ricker]. There also were no significant differences in seed production between grazed and ungrazed collections of Indian ricegrass from the Chaco Canyon study site when transplanted and grown in a common garden. This indicated that long-term protection from livestock grazing probably had not genetically (ecotypically) altered seed production potential. Both grazed and ungrazed transplants of Indian ricegrass differed in seed production from the cultivars 'Paloma' and 'Nezpar'. Nezpar produced the greatest seed yield $(312 \mathrm{~kg} / \mathrm{ha})$, while Paloma had the lowest yield $(78 \mathrm{~kg} / \mathrm{ha})$. Defoliation about 1 June over a 2-year period reduced seed production and nitrogen fertilization did not increase seed yield.

Previous grazing history had little effect on seed germination, but there were significant differences in germination among some collections and cultivars of Indian ricegrass. Germination was less than $5 \%$ for all entries. A tetrazolium viability test showed that seed of native strains were more viable than those of Paloma. Dormancy is a troublesome, but desirable, trait of Indian ricegrass seed for use in droughty areas.

Key Words: Oryzopsis hymenoides, ecotypic variation, protection, defoliation, germination, viability

Use of native-grass seed has increased dramatically in recent years. Native grasses are planted frequently in revegetation of marginal croplands in the Conservation Reserve Program, on disturbed areas in National Parks, and in mined land reclamation programs. Indian ricegrass [Oryzopsis hymenoides (Roem. and Schult.) Ricker] is a cool season native bunchgrass that may be useful in reclamation of many arid and semiarid areas in the west-

\footnotetext{
We would like to thank Drs. Charles Bonham, Mark Brick, Wayne Leininger, Walter Herriman, Tom Vaughan, Adrian Fisher, and Mark Stack for their assistance throughout the course of this study. The U.S. Park Service, Bureau of Land Management, and Southwestem Colorado Research Center are recognized for granting permission to use their land for this study.

Manuscript accepted 25 Feb. 1997.
}

\section{Resumen}

El potencial de producción de semilla de Oryzopsis hymenoides [(Roem. y Schult.) Ricker], de la región semiárida de Chaco Canyon en el sudoeste de los Estados Unidos, sometida a 50 años de pastoreo intenso no fue significativamente inferior a la de individuos en clausura. Tampoco se detectaron diferencias en la producción de semilla de individuos provenientes de colecciones pastoreadas y protegidas transplantados a un jardín común. Estos resultados indican que las condiciones de protección de pastoreo del ganado probablemente no afectaron el potencial genético (cambios ecotípicos) de producción de semilla. Individuos transplantados de ambos grupos (pastoreados y protegidos) sin embargo, exhibieron una producción de semilla diferente a la de los cultivares. 'Paloma' y 'Nezpar'. El mayor rendimiento correspondió al cultivar Nezpar (312 kg/ha) mientras que el rendimiento más bajo correspondió al cultivar Paloma (78 $\mathrm{kg} / \mathrm{ha}$ ). Defoliaciones producidas alrededor del $1^{\circ} \mathrm{de}$ junio por un lapso de dos años redujeron la producción de semilla. La fertilización con nitrógeno no incrementó rendimientos.

La germinación se vio poco afectada por la historia de pastoreo, sin embargo se encontraron diferencias significativas de germinación de algunas colecciones y cultivares de Oryzopsis hymenoides. En ningún caso se lograron valores superiores al 5\% de germinación. Pruebas de tetrazolio demostraron que la viabilidad de lineas nativas es superior a la del cultivar Paloma. Mientras que la dormancia de las semillas de Oryzopsis hymenoides constituye una caracteristica problemática, es por otro lado un atributo deseable en semillas a utilizar en regiones sometidas a sequías.

ern United States. However, variable seed production (Hafenrichter et al. 1968, Booth et al. 1980, Riley et al 1984, Fisher et al. 1987, Jones and Nielson 1991) and seed dormancy characteristics have limited its use by seed growers and in some revegetation programs (Jones 1990). A few improved strains of the grass have been developed, but native ecotypes may have some desirable characteristics such as drought and salinity tolerance, low seed dormancy, and nutritional qualities that should be considered for improvement programs and in revegetation efforts (Jones and Nielson 1989).

High dormancy of Indian ricegrass seed has caused concern for many years and a number of studies have been conducted to 
investigate dormancy mechanisms and methods for breaking dormancy to improve seed germination of this species (Stoddart and Wilkinson 1938, Toole 1940, Clark and Bass 1970, McDonald and Khan 1977, Zemetra et al. 1983, Zemetra and Cuany 1984, Young and Evans 1984, Young et al. 1985, Jones and Nielson 1992). Seed dormancy is a mechanism to optimize the distribution of germination over time, and its importance is best illustrated in an ecological context (Bewley and Black 1982). Seeds of many species, including Indian ricegrass, show variability in the degree of dormancy and release from dormancy. Thus, they exhibit irregular germination. This behavior, which is of considerable survival value, ensures that not all new seedlings will be exposed to hazardous periods after sced germination. Harper (1977) pointed out that seed and vegetative dormancy was part of the adaptation of organisms to temporal variations in the environment, and to successful dispersal.

The main objectives of this study were to determine how longterm heavy grazing (versus protection) and different intensities of defoliation affected seed production characteristics of Indian ricegrass under both natural and cultivated conditions. Seed yield, germination, and viability also were compared among native entries and improved cultivars from contrasting origins.

\section{Materials and Methods}

Experiments were conducted at 2 study sites (Chaco Canyon, N.M. and Cortez, Colo.) located in the Four Corners Region of the southwestern United States. The Four Corners Region is the southeastern tip of the Great Basin Desert which occupies parts of New Mexico, Colorado, Wyoming, Utah, Idaho, Oregon, California, Arizona, and most of Nevada. Indian ricegrass is widely distributed within and adapted to this region.

\section{Chaco Canyon Study}

Ten non-defoliated plants of native Indian ricegrass in a natural community were selected at random from each of 6 plots in 2 study areas (grazed and protected). The plots were located at the Chaco Canyon study site within and adjacent to Chaco Canyon National Monument that was previously described by Trlica and Orodho (1989) and Orodho et al. (1990). These plots were located on 3 topographic positions (hilltop, hillside, and swale) within each of 2 areas: heavily-grazed for 50 years or more, and protected inside the national monument for 50 years. The 3 plots in the heavily-grazed area were fenced to exclude livestock during the study period. Seeds (strictly florets) were harvested from each of the selected plants twice a week from seedripe in mid-June to the end of seed production in mid-July. Seeds were shaken from each plant into a large paper sack held over the entire plant, and harvests were combined to give total seed yield for each plant for the growing season.

Another experiment was carried out in these same 6 plots. Four defoliation intensities $(0,30,60,90 \%$ removal of photosynthetic tissues) were each applied to 4 Indian ricegrass tussocks selected at random in each plot and marked. Defoliation was done by clipping plants at the anthesis stage in early June 1984, and clipping was repeated at the same phenological stage in 1985. Seeds from these plants were shaken loose and collected in a bag twice each week, from the beginning of the first seed ripe stage until the end of the seed shatter stage, during 1985. Seed was combined for each plant within each treatment for the entire growing season.

\section{Cortez Study}

Two collections (grazed and ungrazed) and 2 cultivars (Paloma and Nezpar) of Indian ricegrass were transplanted in late April 1984 from field material into a split-plot design with 2 nitrogen (N) levels ( 0 and $50 \mathrm{~kg} / \mathrm{ha}$ ) applied on the main plots, 2 defoliation treatments (unclipped and clipped) on sub-plots, and 4 collections or cultivars of Indian ricegrass in the sub-sub-plots. Five transplants were planted at a spacing of $75 \times 75 \mathrm{~cm}$ for cach treatment in 4 replications. Nitrogen and defoliation treatments were applied at the same time in early June of 1984 and late May 1985. The plots were hand weeded whenever necessary. Seeds were harvested twice a week from July to August. Seed was collected and combined as described previously to give total seed yield for each plant for the growing season.

The harvested seed from the Cortez seed production experiment and the 2 experiments at the Chaco Canyon study site were cleaned manually by rubbing them gently on the back of burlap carpet with a wooden block that was faced with ridged, hard rubber stairtread material. Good seed was separated from empty seed and 'fuzz' by use of a large column (single column height) of a seed blower. The cleaned seeds were then weighed.

\section{Seed Germination and Viability Studies}

Seed Collection-Seed germination for 6 collections and 3 other strains of Indian ricegrass was evaluated in a growth chamber experiment. All seed had been harvested during the summer of 1984 and all were tested at 6 to 8 months of age. Seed from 6 of these entries were collected as 6 bulks from previously grazed and ungrazed sites at the Chaco Canyon plots located on hilltop, hillside, and swale positions described earlier. Three other strains (NAPI, Paloma, and Nezpar) were obtained by special request. NAPI and Nezpar seed was obtained from the Southwest Seed Company, Cortez, Colorado. The company had originally collected the NAPI seed as a roadside harvest from the Navajo Agricultural Project, Inc. near Farmington, New Mexico. Paloma seed was obtained from a certified seed grower in southeastern Utah, approximately $90 \mathrm{~km}$ northwest of the Cortez study site. Seed of the various collections and strains of Indian ricegrass was uniformly cleaned with an air-screen seed cleaner and by hand. The seed was manually passed through several sizes of screens to remove chaff. A blower was used to remove light seeds, chaff, and seed fuzz.

To insure more uniformity of cleaned seeds of the 9 entries, only heavy seeds were used. The heavy seeds were separated from the light seeds by the density method described by Toole (1940). The fully-developed Indian ricegrass seed was heavier (denser) than undeveloped seed (Stoddart and Wilkinson 1938). Therefore, seeds that did not sink in water after 5 min were removed and discarded. Seeds that sank (mature and fully filled) were blotted dry, air dried in the sun for 6 hours, and utilized in the germination experiment.

Scarification-A modified commercial scarifier, the same one used by Zemetra et al. (1983), was used to scarify seeds for the germination experiment. This scarifier used rotating batts to propel the seeds against an abrasive surface. To minimize embryo damage, a variable rheostat was used to reduce the number of revolutions per $\min (\mathrm{rpm})$ of the batts to a speed which scarified the seeds without crushing them. The seeds of the 9 entries were each divided into 2 lots, 1 of which was scarified while the other was left as the unscarified control. 
Seed Weight-Samples of 100 seeds each were randomly selected from scarified and unscarified lots for each Indian ricegrass entry and weighed. The average weight of 4 samples was used as the 100-seed weight for each of the scarified and nonscarified seed treatments for each of the 9 entries.

Tests were conducted to determine germination percentage and viability of the 9 entries of Indian ricegrass as affected by the 2 scarification treatments. Because of space limitation in the growth chamber, and the anticipated work load in carrying out tetrazolium chloride (TZ) tests at the end of every germination period, each of the 4 replications was run at a different time.

One hundred seeds of each entry were selected at random for each replication and imbibed in water. Seeds were then placed on moist blotter paper in $11 \times 11 \times 2.4-\mathrm{cm}$ clear plastic boxes. Seeds of all entries were prechilled in a dark growth chamber set at $4^{\circ} \mathrm{C}$ for 28 days in accordance with rules from the Association of Official Seed Analysts (AOSA 1978). Toole (1940) had also recommended that prechilling was effective if Indian ricegrass seeds were chilled for at least 28 days. The seeds were frequently checked during the prechill period and tap water was added whenever necessary to maintain the seed in moist conditions. After prechilling, the seed boxes were transferred into a dark growth chamber which was set at $15^{\circ} \mathrm{C}$ as recommended by AOSA (1978) to allow for seed germination.

Germination data were taken every 7 days by counting and removing germinated seeds (those showing both radicle and hypocotyl emergence) from each seed box, which was kept moist as needed. Those seeds that had not germinated after 21 days were cut in half longitudinally to expose the embryo, and the half showing the best mid-section view of the embryo was soaked in a $0.1 \%$ solution of $\mathrm{TZ}$ for 4 hours. The seed boxes were placed in a chamber at a temperature of $32^{\circ} \mathrm{C}$ to speed up the $\mathrm{TZ}$ reaction. Those seeds that developed a distinct brick red color in the embryo area were considered viable, but dormant. These numbers were then added to the numbers that had already successfully germinated to get the total number of viable seed. Those seeds that showed no reaction to the $\mathrm{TZ}$ treatment were considered dead (Ebener 1988).

\section{Data Analysis}

All data on seed yield, seed weight, germination and viability percentages were analyzed with factorial analysis of variance procedures (Steel and Torrie 1980). When significant differences $(P \leq 0.05)$ were detected, Tukey's Test was used to separate significant $(P \leq 0.05)$ means.

\section{Results and Discussion}

\section{Seed Production}

Chaco Canyon Study-Long-term heavy grazing prior to the 1year exclusion, compared with 50 years of protection from livestock grazing, had not affected seed production of Indian ricegrass at the Chaco Canyon study site (Fig. 1). There were also no significant differences in seed yield of plants among the 3 topographic positions. There were, however, differences in seed yield among the 4 defoliation intensities under both grazed and protected conditions. As anticipated, there was a progressive decrease in seed yield with an increase in defoliation intensity. The most severe defoliation intensity $(90 \%)$ resulted in a $90 \%$ reduction in seed yield.

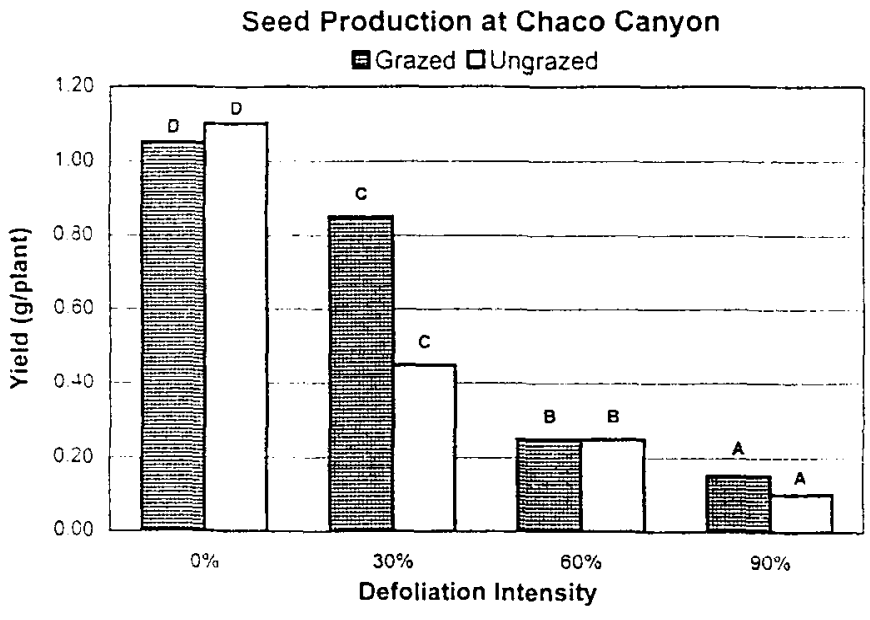

Fig. 1. Average seed yield (g/plant) for Indian ricegrass at the Chaco Canyon study site as affected by long-term heavy graxing and defoliation intensity. Means for a defoliation intensity at 2 grazing levels labeled with a similar letter are not significantly different $(P>0.05)$.

Cortez Study-Nitrogen (N) application at the rate of $50 \mathrm{~kg} / \mathrm{ha}$ during late May or early June of each year did not significantly increase seed production of Indian ricegrass grown in a common garden at the Cortez study site during both years of study. Therefore, all subsequent data on seed yield were analyzed by combining data for the $\mathrm{N}$ treatments. It is likely that the applied nitrogen did not affect seed yield because moisture was limiting at the time of $\mathrm{N}$ application or that there was ample available nitrogen in this cultivated soil for plant growth.

There was a significant increase in seed yield of transplants of Indian ricegrass at the Cortez study site during the second year of production (Fig. 2). More seeds per unit of inflorescence were produced during the second year.

Defoliation at the $90 \%$ level did not causc any significant decrease in seed yield for any collection or cultivar of Indian ricegrass at the Cortez study site during 1984, probably because seed yield was low during the first year of establishment for the transplants (Fig. 2A). Clipping, however, did cause a drastic decrease in seed yield of both native collections and cultivars of Indian ricegrass during 1985 (Fig. 2B). There also may have been some carry over effect of clipping from 1984 that resulted in a reduction in seed yield when plants were clipped again in 1985.

There were significant differences in seed yield among the collections and cultivars of Indian ricegrass tested at the Cortez study site (Fig 2). There was, however, no significant difference between grazed and ungrazed collections of Indian ricegrass that originated from Chaco Canyon. This indicated that long-term heavy grazing, versus protection from livestock use for 50 years, did not result in the evolution of a different strain of Indian ricegrass, at least in seed production potential. However, the Chaco Canyon collections differed in seed production from both Paloma and Nezpar cultivars. Nezpar produced more seed $(312 \mathrm{~kg} / \mathrm{ha}$ in 1985) than the Chaco Canyon material (104 kg/ha), and Paloma often produccd less seed $(78 \mathrm{~kg} / \mathrm{ha}$ ) than other strains during the 2-year study. This indicated that the non-domesticated Chaco Canyon ecotype had the potential to produce more seed in the Four Corners Region than did the cultivar Paloma that originated on the eastern slope of the Rocky Mountains (Anonymous 1974). It also showed that a cultivar (Nezpar) originally collected in northern Idaho could produce more seed than the local ecotype. 

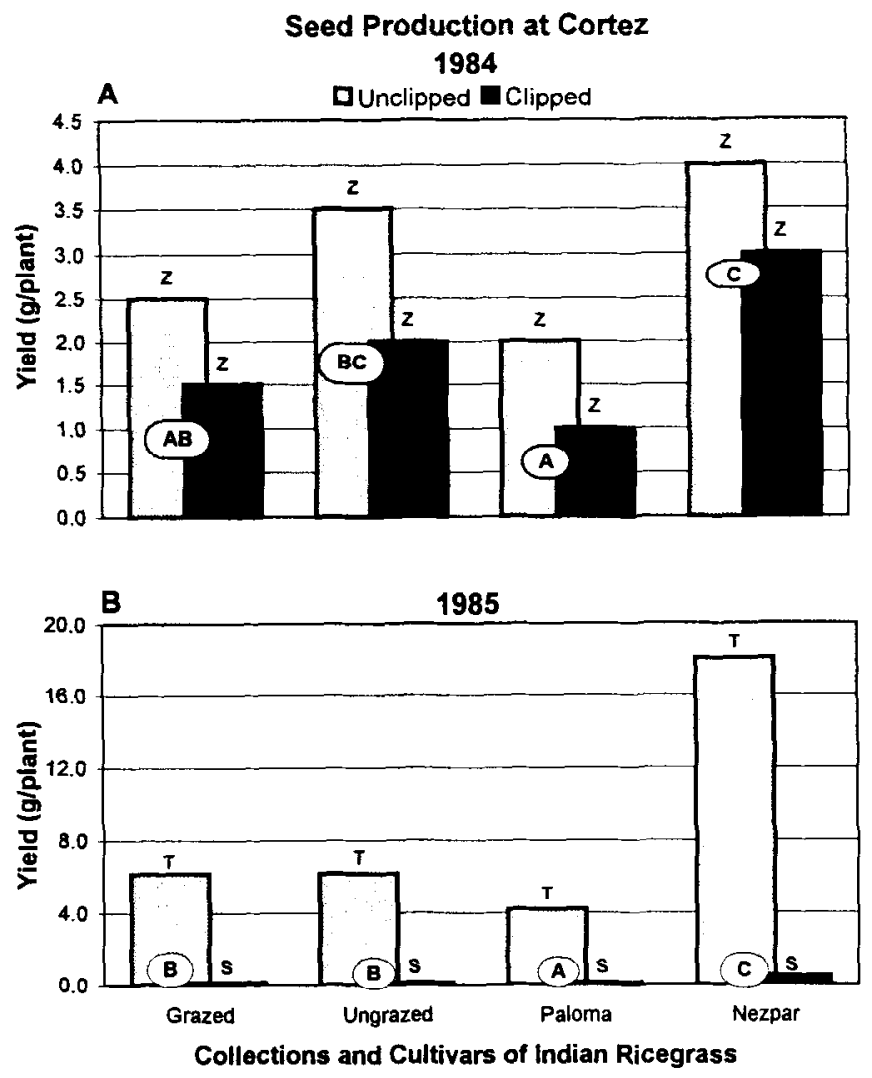

Fig. 2. Average seed yield (g/plant) for collections and cultivars of Indian ricegrass during $1984(\mathrm{~A})$ and 1985 (B) at the Cortez study site as affected by defoliation. Means for entries labeled with similar circled letters are not significantly different $(P>0.05)$. Means for defoliation treatments within each collection or cultivar labeled with a similar letter above the bars are not significantly different $(P>0.05)$. Note differences in scale for yields between the 2 years.

\section{Seed Germination and Viability}

Seed weight varied considerably among the 9 entries of Indian ricegrass tested. The average 100 -seed weight from the Chaco Canyon collections ranged from 479 to $561 \mathrm{mg}$. Paloma seed was heavier than most Chaco Canyon collections, whereas Nezpar had the lightest secds (Fig. 3A). This strongly suggested that seed size is an inheritable characteristic in Indian ricegrass, as noted by Zemetra and Cuany (1984). These findings supported work by Bohmont and Lang (1957) and Zemetra et al. (1983) who found ecotypic differences in seed weight of Indian ricegrass. Young and Evans (1984) observed a consistent occurrence of a relatively constant ratio of big and small seeds produced by different populations of Indian ricegrass, but polymorphism was not noticeably present in our study.

There were significant variations in seed viability 6 months after harvest among the different entries of Indian ricegrass. The improved Nezpar strain had very high seed viability; whereas, the improved Paloma strain had the lowest seed viability (Fig. 3B). All collections from Chaco Canyon had higher viability than did the Paloma strain.

Results of seed germination tests indicated that there were no significant differences in germination among the native strains (Chaco and NAPI) of Indian ricegrass tested (Fig.4). These strains had lower seed germination than the improved strain of
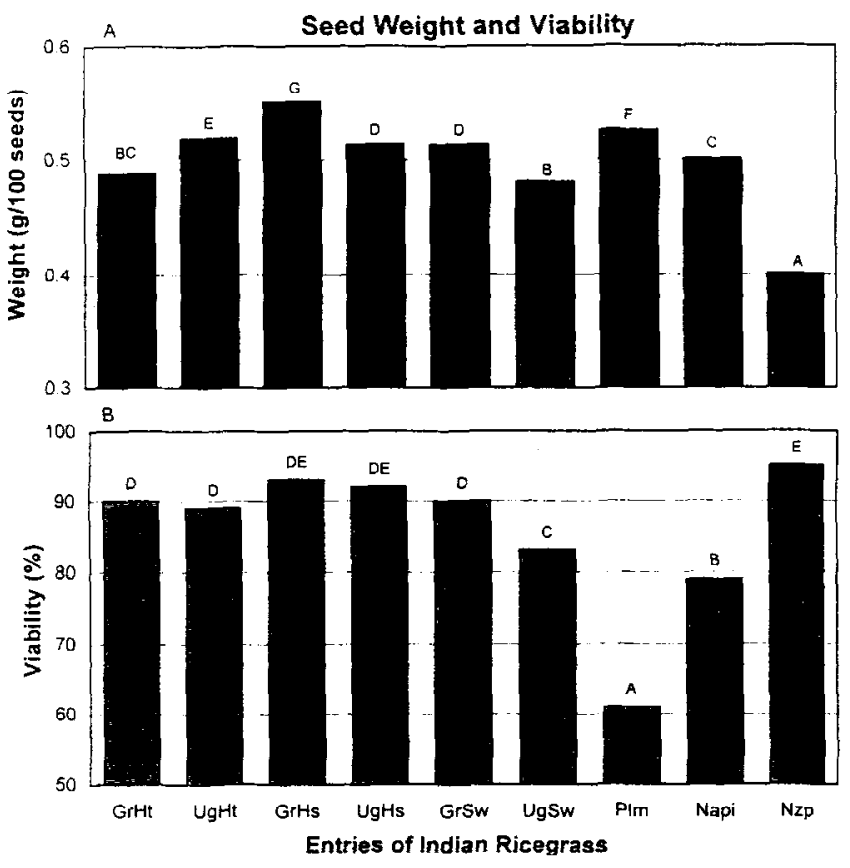

Fig. 3. Average seed weight (A) and viability (B) for 9 entries of Indian ricegrass. Means labeled with a similar letter are not significantly different $(P>0.05)$. The entries are identified as $\mathbf{G r}$ (grazed), Ug (ungrazed), Ht (hilltop), Hs (hillside), Sw (swale), Plm (Paloma), Napi (Navajo Agricultural Project, Inc.), and Nzp (Nezpar).

Paloma. Seed germination for Nezpar was not different from seed germination of native strains. Zemetra and Cuany (1984) found that seed wcight of Indian Ricegrass was not highly correlated with germination percentage, as was found in the present study.

Mechanical scarification of seed caused a significant increase in seed germination of most entries of Indian ricegrass, except for grazed and ungrazed hillside populations. This supported results obtained by Zemetra et al. (1983) who found that mechanical scarification increased germination of Indian ricegrass seed. Because of variability in secd weight, size and seed cover thickness, application of a uniform scarification treatment for Indian

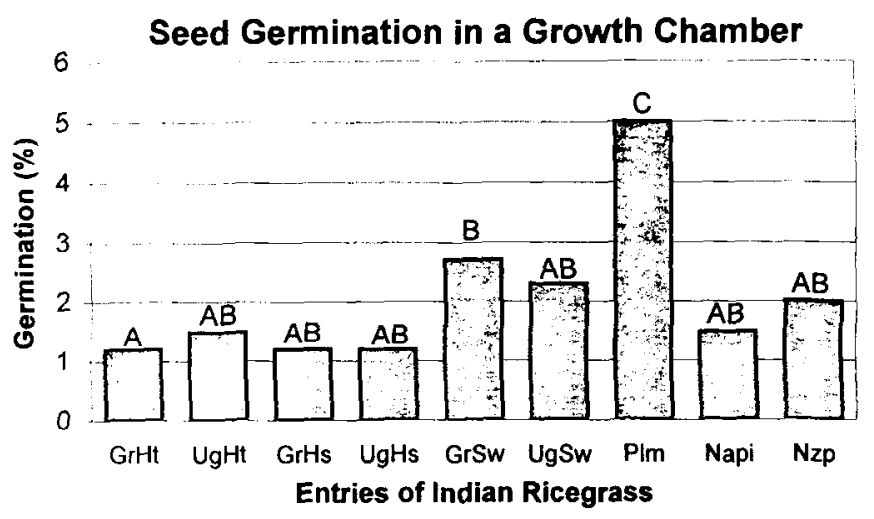

Fig. 4. Germination percentage for 9 entries of Indian ricegrass testcd in the growth chamber. Means labeled with a similar letter are not significantly different $(P>0.05)$. The entries are identified in Fig. 3. 
ricegrass seed is a problem which may explain why some nonuniform germination percentages and stand establishment are obtained. Strains of Indian ricegrass have been shown to differ in composition of their polymorphic forms and germination characteristics (Young and Evans 1984). Zemetra and Cuany (1984) recommended that lemma thickness be utilized to determine proper acid scarification procedures to minimize seed damage and maximize germination.

\section{Summary and Conclusions}

Collections and cultivars of Indian ricegrass had considerable variation in seed weight, seed germination, and viability. Longterm heavy grazing, versus $\mathbf{5 0}$ years of protection from domestic livestock grazing, had no significant effect on these characteristics. Previously-grazed plants that had been protected from grazing for 1 year did not yield any less seeds than plants that had been protected for 50 years in Chaco Canyon National Monument. This suggested that either ecotypic differentiation had not occurred in the 50 years, or that the 2 populations were not isolated. Orodho and Trlica (1990) also found little evidence for ecotypic differentiation for biomass production and carbohydrate reserve levels in these Chaco Canyon collections. We tried to minimize pollen transport by selecting plots at appropriate distances, but there might have been some unknown factors in seed transport by wind and animals.

Defoliation at the beginning of anthesis of Indian ricegrass in a natural community at Chaco Canyon reduced seed production, and the greatest reduction resulted from the most severe (90\%) defoliation intensity. Defoliation in late May or early June for 2 consecutive years in a common garden study near Cortez, Colorado resulted in a massive reduction in seed production. Therefore, if high seed production is the objective, grazing or harvesting of Indian ricegrass forage before seed collection should be avoided.

Collections of Indian ricegrass from the Chaco Canyon study site were superior in seed production to Paloma, but inferior to the Nezpar cultivar. The 2 collections from the Chaco Canyon study site should be evaluated and improved for their promising drought tolerance, persistence under heavy grazing (Orodho et al. 1990), high leaf-to-stem ratio (Trlica and Orodho 1989, Orodho and Trlica 1990), and seed production potential for revegetation purposes. While Nezpar is a promising strain for seed production in southwestern Colorado and areas of higher elevation, the collections from the Chaco Canyon study site might be useful to develop a strain adapted to the vast semiarid and arid areas of the Four Comers Region that receive low annual precipitation.

Seed viability of native strains of Indian ricegrass was consistently high, while seed germination for these strains was consistently low. This suggested a dormancy mechanism that may be of significant biological value for the long-term successful survival of this species under semiarid or arid conditions. It is probable that this mechanism has allowed native Indian ricegrass to optimize the timing of germination for its successful perpetuation in a harsh environment with erratic and low rainfall. A plant improvement program should not jeopardize the long-term survival mechanism of this species through development of a drought resistant strain free of its useful dormancy trait.

\section{Literature Cited}

Anonymous. 1974. Notice of naming and release of 'Paloma' Indian ricegrass for soil stabilization and range forage. USDA Soil Conservation Service. Los Lunas, N.M.

Association of Official Seed Analysts (AOSA). 1978. Rules for testing seeds. J. Seed Tech. 3:45.

Bewley, J.D. and M. Black. 1982. Physiology and biochemistry of seeds in relation to germination. Vol. 2. Viability, Dormancy and Environmental Control. Springer-Verlag, N.Y.

Bohmont, B.L. and R. Lang. 1957. Some variations in morphological characteristics and palatability among geographic strains of Indian ricegrass. J. Range Manage. 10:127-131.

Booth, D.T., C.G. Howard, and C.E. Mowry. 1980. 'Nezpar' Indian ricegrass: description, justification for release, and recommendations for use. Rangelands 2:53-54.

Clark, D.C. and L.N. Bass. 1970. Germination experiments with seeds of Indian ricegrass [Oryzopsis hymenoides (Roem and Schult) Ricker]. Proc. Assoc. Official Seed Anal, 60:226-239.

Ebener, W.C. 1988. Comparison of viability of Indian ricegrass, Oryzopsis hymenoides, seeds. M.S. Thesis. Colo. State Univ., Fort Collins, Colo., $177 \mathrm{p}$.

Fisher, A.G., M.A. Brick, R.H. Riley, and D.K. Christensen. 1987. Dryland stand establishment and seed production of revegetation species. Crop Sci. 27:1303-1305.

Hafenrichter, A.L., J.L. Schwendiman, H.L. Harris, R.S. MacLaughlan, and H.W. Miller. 1968. Grasses and legumes for soil conservation in the Pacific Northwest and Great Basin states. USDA Handbook No. 339, Washington, D.C.

Harper, J.L. 1977. Population biology of plants. Academic Press, London.

Jones, T.A. 1990. A viewpoint on Indian ricegrass research: its present status and future prospects. J. Range Manage. 43:416-420.

Jones, T.A. and D.C. Nielson. 1989. Self-compatibility in 'Paloma' Indian ricegrass. J. Range Manage. 42:187-190

Jones, T.A. and D.C. Nielson. 1991. High seed retention of Indian ricegrass PI 478833. J. Range Manage. 45:72-74.

Jones, T.A. and D.C. Nielson. 1992. Germination of prechilled mechanically scarified and unscarified Indian ricegrass seed. J. Range Manage. 45:175-179.

McDonald, M.B., Jr. and A.A. Khan. 1977. Factors determining germination of Indian ricegrass seeds. Agron. J. 69:558-563.

Orodho, A.B. and M.J. Trlica. 1990. Clipping and long-term grazing effects on biomass and carbohydrate reserves of Indian ricegrass. $J$. Range Manage. 43:52-57.

Orodho, A.B., M.J. Trlica, and C.D. Bonham. 1990. Long-term heavy grazing effects on soil and vegetation in the four corners region. Southwest. Nat. 35:9-14.

Riley, R.H., A.G. Fisher, and M.A. Brick. 1984. Dryland seed production in revegetation species. p.161-169. In: Proc. High Altitude Reveg. Workshop. No. 6., Colo. Water Resources Res. Institute Info. Series No. 53, Colo. State Univ., Fort Collins, Colo.

Steel, R.G.D. and J.H. Torrie. 1980. Principles and Procedures of Statistics: A Biometric Approach. McGraw-Hill, New York, N.Y 633 p.

Stoddart, L.A. and K.J. Wilkinson. 1938. Inducing germination in Oryzopsis hymenoides for range reseeding. J. Amer. Soc. Agron. 30:763-768.

Toole, V.K. 1940. The germination of seed of Oryzopsis hymenoides. J. Amer. Soc. Agron. 32:33-41.

Trlica, M.J. and A.B. Orodho. 1989. Effects of protection from grazing on morphological and chemical characteristics of Indian ricegrass, Oryzopsis hymenoides. Oikos 56:299-308.

Young, J.A. and R.A. Evans. 1984. Germination of seed of 'Paloma' and 'Nezpar' Indian ricegrass. J. Range Manage. 37:19-21.

Young, J.A., R.A. Evans, and D.A. Easi. 1985. Enhancing germination of Indian ricegrass seeds with sulfuric acid. Agron J. 77:187-358.

Zemetra, R.S. and R.L. Cuany. 1984. Variation in lemma thickness in Indian ricegrass: implications for dormancy, scarification, and breeding. Crop Sci. 24:1082-1084.

Zemetra, R.S., C.M. Havstad, and R.L. Cuany. 1983. Reducing seed dormancy in Indian ricegrass, Oryzopsis hymenoides. J. Range Manage. 36:239-241. 